\title{
ALL THINGS CONSIDERED? ALTERNATIVE REASONS FOR HAMSTER EXTINCTION
}

\author{
STEFANiE MONECKE
}

Institute for Cellular and Integrative Neuroscience, department Neurobiology of Rhythms, University of Strasbourg Address for correspondence

INCI, Department Neurobiology of Rhythms, University of Strasbourg, 5 rue Blaise Pascal, 67084 Strasbourg, France, 00333884567 34, stefanie.monecke@inci-cnrs.unistra.fr

Abstract. In 2002 a pest biologist (LeIRs 2002) calculated the survival chances of the European hamster (Cricetus cricetus) according to data provided by participants of the meeting of the International Hamster Workgroup in Tongeren. His model was based predominantly on demographic data as birth rates and predicted that the European hamster will be extinct in Western Europe within the next 50 years. Since then, the mean number of litters females raise in a year has diminished from 2-3 to 1-2. It is thus to be feared that the remaining time is only half as long as predicted and extinction might occur around 2030.

However, since then hamster protection measures have improved considerably and two major milestones have been reached: (1) we are able to breed captive hamsters in a sufficient number and (2) most released hamsters survive long enough to reproduce once. Thus, at the present state we can claim that the hamster won't go extinct as long as such breeding and releasing programs are in place. However, we haven't achieved a state yet at which it is clear that the hamster will survive with its own means when such programs are stopped. To work on this will be the task of the coming years.

This review might be a starting point for that. It reflects on which other factors possibly impair the survival of European hamster populations besides some aspects of modern agriculture, thus it searches for parameters which are not yet considered in conservation programs. Historical data as well as observations and research data from other species are reviewed. Additionally, new insights from the subterranean life of European hamsters in outdoor terrariums are presented, which suggest that the soil as

Contribution of 26th Meeting of the International Hamster Workgroup, 15-17th November 2013, Poznań, Poland 
habitat might need more attention in conservation. However, this conjecture can provide only new ideas, which still have to be confirmed by research. The intention is to spark a lively discussion on such potential alternative reasons for the decline of European hamsters, whether some of them are worth being investigated and whether we overlooked something. There is not much time left.

\section{INTRODUCTION}

The dramatic decline of European hamsters (Cricetus cricetus) was first remarked only in Western Europe. Unfortunately, the lack of information from Eastern countries of the distribution area was misinterpreted and it was falsely assumed that the situation was stable there. Consequently, protection measures of the past two decades where focussed predominantly only on the elimination of disadvantages which the early industrialization of agriculture in Western Europe had for the hamsters. While there is no doubt that certain aspects of modern agriculture are unfavourable for European hamsters, there is a strong doubt that they are the only reason for extinction. Moreover, it can be doubted that they are the main cause for extinction. This article should be understood as a conjecture reflecting on which other reasons might account for the species decline.

The distribution area of European hamsters is quite large covering most parts of the temperate zone of the Eurasian continent (NECHAY 2000), where the animals live predominantly on agricultural fields (WEINHOLD and KAYSER 2006). Recent studies showed that European hamster populations decline dramatically in most parts of its range (Fig. 1): in Western Europe as a whole (for review see (Nechay 2000), in the Czech Republic (Tkadlec et al. 2012), in Poland (Ziomek

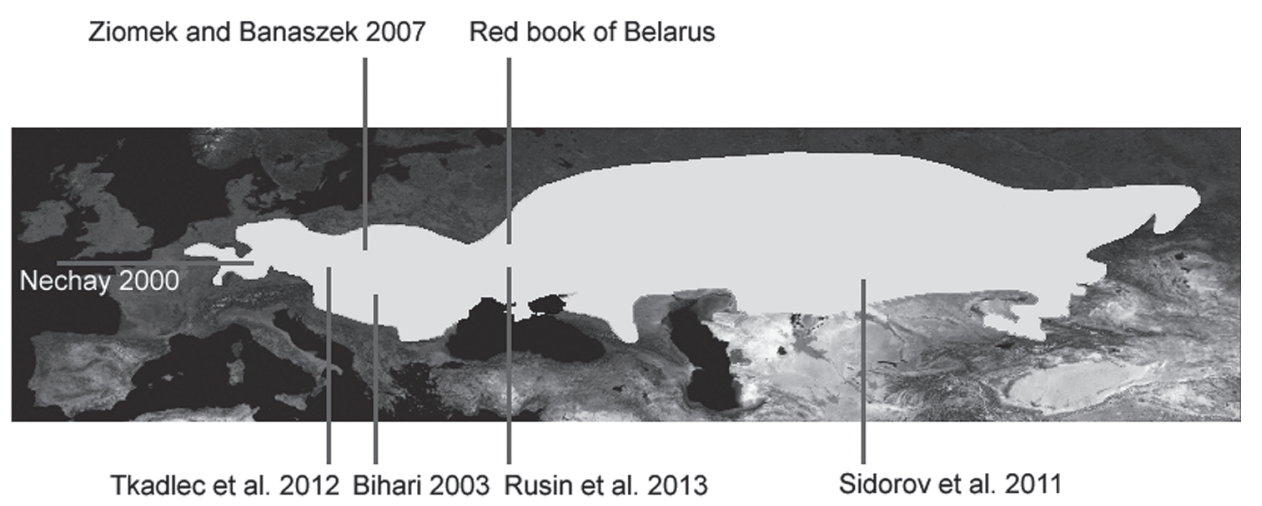

Fig. 1: Global decline of the European hamster. Distribution map of European hamsters (created by Tobias Reiners according to 2008 IUCN map, modified) with populations observed to be in decline noted For details see text. 
and BANAszek 2007), in Hungary (Bihari 2003), in the Ukraine (Rusin et al. 2013) and Belarus (http://redbook.minpriroda.gov.by/animalsinfo.html?id=12) as well as in Siberia (Sidorov et al. 2011).

Climate change would well fit as a reason for a global decline, most of all since a relation between the size of the European hamster's distribution area and historic or prehistoric changes in climate has been demonstrated (NeUmann et al. 2005). While the present-day temperature increase might thus well account for the decline of European hamsters at the periphery of the distribution area, it is unlikely that this it is responsible for the recently discoveredl decline in it's centre, the Ukraine (Rusin et al. 2013), which is known to be the (pre)historic refuge of European hamsters (Neumann et al. 2005). The climate change is thus not the only reason for the global hamster decline.

However, the global decline disfavours the hypothesis that modern agriculture is a main reason since such a large area offers a broad variety in landscapes, climates, agricultural philosophies and crop cultivations. Moreover, a demographic model which a pest biologist applied on the European hamster revealed that a low reproductive rate alone is sufficient to cause the extinction of the European hamster (LeIRS 2002). According to this model, a female needs to raise 3-4 litters per year to keep the population stable over the next 100 years with the species-typical occasional outbreaks of populations. However, according to the participants of the $10^{\text {th }}$ meeting of the International Hamster Workgroup, only 2-3 litters are raised per year per female, which would lead inevitably to extinction around the year 2050 without considering any mortality factor. Nowadays, only 1-2 litters per female are reported in many regions and many years, so that we might have to expect extinction around 2030. While this study gives the first alternative reason for extinction, namely low reproduction rate which will be discussed later in this article, it shows also that there is not much time left. If something needs to be added to the current protection measures, it should be now.

First, we have to ask when the decline of hamsters started. In contrast to the general assumption, the decline in European hamster populations had already started when agriculture was still far from being modern. The number of hamster furs which were bought by the German Democratic Republic decreased dramatically from 1952 to 1982 (WeINHOLD and KAYSER 2006). Furthermore, a data collection of historical records of trapped hamsters in Thuringia/Germany, either for fur trapping or as pest control, suggests that the decline had started before the 1950s (Fig. 2 from data by Stubbe and Stubbe 1998). The recordings of a single hamster trapper from 1915 to 1980 suggest that the decline had started as early as 1925 when $10-12$ hamsters could be captured on 1 hectare. In contrast, from 1946 to 1980 only around four hamsters per hectare could be trapped (Stubbe and Stubbe 1998, Ulbrich and Kayser 2004). From these records, we can't be sure that in each year the maximum number of hamsters possible was trapped. Nevertheless, the data shows, at least for Germany, that the dramatic decline had started long before agriculture was "modern". These examples 


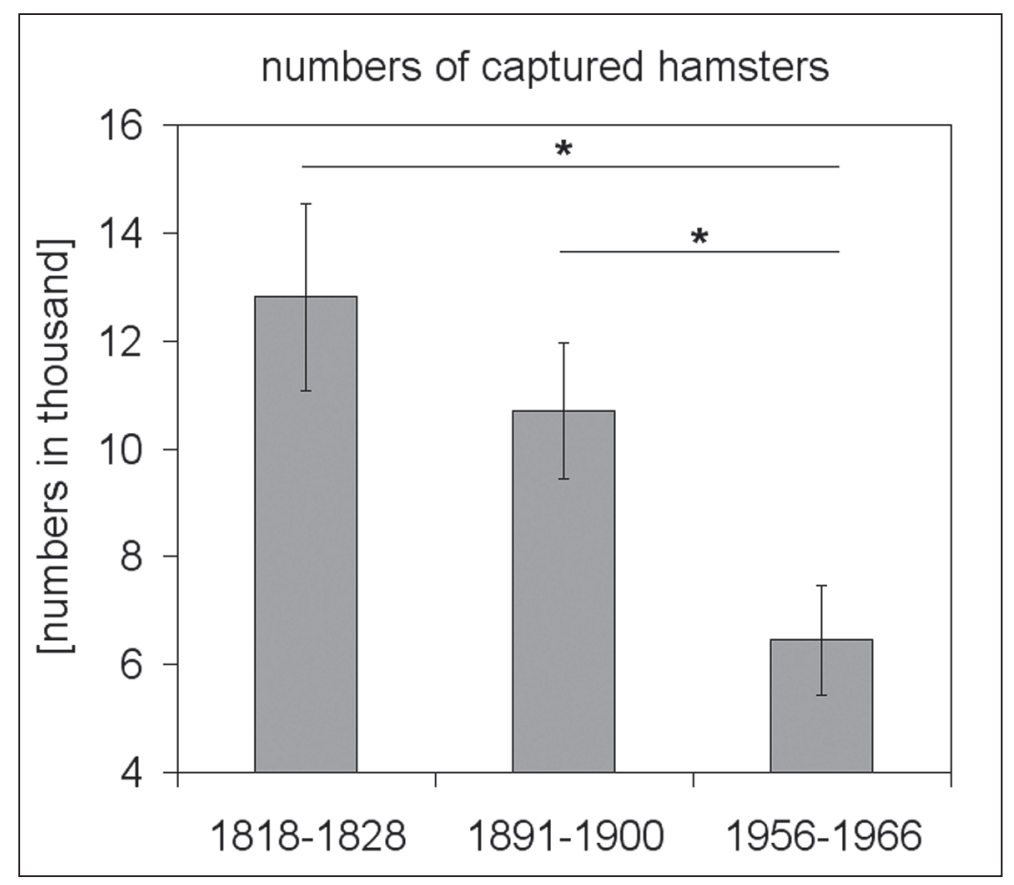

Fig. 2: Numbers of trapped hamsters over three decades in the farmlands of the town and the county of Gotha (Thuringia, Germany). Data were gained from Fig. 1 in Stubbe and Stubbe 1998), which was digitized and numbers were calculated pixel per pixel. Asterisks indicate a significant decrease $(p<0.05$; ANOVA followed by a LSD posthoc test) between 10 to 11 years periods. Note that the single years of 1817 and 1890 were excluded from this analysis even though data were indicated in the original graph. These years were obviously mass outbreak years.

show two things: 1) the more recent hamster decline observed in Western Europe at the end of the $20^{\text {th }}$ century is not the start of decline but might present an "extinction vortex" already in progress, i.e. when the population is already so weak that small disturbances have a huge negative impact 2) we might have to search for the reason for extinction not only in the present but also in the past.

\section{IS THE SOIL STILL SUITABLE?}

The soil might have changed slowly and unnoticed over decades. In current protection measures it is mostly not considered. The so-called hamsterfriendly management concerns only the above ground part of the hamster's habitat by providing food and cover during most parts of the year. However, a European hamster spends at least three quarters of its life in it's burrow in the earth. 
Recently, we built a new experimental setting in terrariums to investigate how such a burrow is constructed. A preliminary data analysis showed that constructing the first part of the entrance seemed to be surprisingly difficult, since the soil layer above the first gallery is initially quite thin and fragile before the hamster reaches a greater depth. Thus, if the soil is not well settled, the entrance will collapse and the hamster has to restart. In natural conditions ploughing regularly renders the top layer of the soil loose and instable. In modern agriculture, ploughing and harrowing might occur more often, more perfectly and deeper as compared to former times. Often, the top $30 \mathrm{~cm}$, if not more, are affected which is more than one body length of European hamsters. With such an unstable surface, the fragile burrow entrance might fall in easily before the body length allows the hamster to reach the stable part of the soil. Up to now, observations on burrow digging in regularly ploughed fields are lacking.

Ploughing might additionally destroy the soil capillaries by which water can evaporate. Moreover, the loosened soil surface allows that precipitation penetrate easily. Both cause an increased moisture content of the soil. However, a hamster burrow needs to be dry otherwise the food stock grows mold quickly. European hamsters need to feed from stored food reserves in euthermic phases between torpor bouts of hibernation; they are unable to hibernate without a food stock within reach (MALAN 2011), even though hibernation would reduce energy expenses (Coburn and Geiser 1996; Song et al. 1996). With a spoiled food stock the animals are likely to die.

In the terrariums, hamsters preferred to dig under horizontal structures, such as a simple wooden plank, which obviously offers a stable cover for the fragile beginning of a gallery. Once the entrance is established the hamster prefers to stick to vertical structures, maybe also for stability reasons. It seems thus beneficial for a hamster in natural conditions to construct at least the winter burrow close to horizontal or vertical structures such as stones or roots from trees or bushes. However, nowadays the soil of agricultural land is thoroughly cleared. In recent years most trees and bushes as field separators have been removed. Replanting hedges and trees at the borders of fields would be a conservation measure for many species above and below ground. Probably, it will also have a positive effect on the soil moisture content since the trees soak up the water. This effect might gain increasing importance in times of global warming where, in some areas during the precipitation-rich winter, temperatures might not drop below the freezing point any more. As a consequence soil moisture content might increase, which can be attenuated by trees and hedges.

Erosion might also be a problem since the soil is left fallow for much of the year. In addition to rising ground water levels, which are observed in areas where industrial ground water use or mining have decreased, this might reduce the thickness of the hamster-suitable soil layer and some habitats might become unsuitable. Furthermore, we know little about the impact of intense gravel mining in river valleys, i.e. close to some hamster habitats, on ground water levels, since gravel usually drains the soil. 
While we already know much about the architecture of hamster burrows (Eisentraut 1928, Kramer 1956, Grulich 1981), little is known about the choice of their locations. Clearly, more research on the soil quality is needed and the soil needs to achieve higher attention in conservation measures. Maybe it is no happenstance that the highest density of European hamsters in France is found on an area in which the soil remains untreated and always covered by organic material (Obernai, excursion site $18^{\text {th }}$ International Hamster Meeting).

The hypothesis that a structure-rich and/or untreated soil might be beneficial for the European hamster is supported by a recent paper on a dramatic decline of the hamster distribution area in the Ukraine (RUSIN et al. 2013). European hamsters vanished nearly completely from the steppe zone but retreated to the forest-steppe zone, which is certainly richer of deep tree roots. Furthermore, the fact that hamsters are doing quite well in some towns (Fеоктіsтova et al. 2013), might be explained by a soil, which is extremely rich of vertical and horizontal structures (foundations of buildings, caves, stones and other demolition waste, tree roots in parks and gardens, pavements, pipelines, cable channels). Moreover, its surface remains in large parts untreated.

\section{WHAT CAN WE LEARN FROM OTHER SPECIES?}

Not only European hamster, but many other hamster species are declining (Nechay 2000). Do they have anything in common? Furthermore, little is reported in the International Hamster Workgroup about the population development of species which share the same ecological network as the European hamster (see Fig. 9.20 in Sidorov et al. 2011)). For example, successful protection measures increased the numbers of birds of prey. Among their main food sources is the European hamster (Allert and Löw 2011, Horal 2011; WichmanN 2011). What about population development in other predators? And what about other prey species in the same habitat? A high population density of the latter might reduce the predation pressure on European hamsters. A more holistic approach might increase the success of species protection.

Other species went extinct; a review of such cases might give valuable insights to explain the dramatic decline of European hamsters. Interesting examples are found in the book "Lonesome George: On the Disappearance of Species" (FrENZ 2012) from which the following example is taken as representative. It is the case of "Martha" the passenger pigeon (Ectopistes migratorius). Martha died on 01.09.1914 at 12:45 at an age of 29 years as the last individual of her species in the Cincinnati Zoo. This was a historic moment since Martha belonged to what had been the most abundant bird species. Interestingly, passenger pigeons were initially considered unspectacular when Europeans invaded the American continent in the middle of the $16^{\text {th }}$ century. None of the naturalists among them described passenger pigeons. About 250 years later, in the early $19^{\text {th }}$ century, a sound like thunder announced a spectacle. The sky went black when passenger pigeons arrived in flocks of a size the world had never seen before or after. The flocks were larger than a square kilometre, it took 
hours for them to pass and the numbers of animals in a single flock were estimated at the incredible number of 3.5 billion. The forest they chose as a nesting place was completely destroyed after the breeding season, since hundreds of birds would share a singletree. Branches broke from the weight of the animals. Moreover, the thick layer of faeces under the trees was toxic. The forests needed years or even decades to recover. Thus, in the early $19^{\text {th }}$ century the passenger pigeon was a veritable pest. They were easy to hunt in these large flocks, one shotgun shot could kill up to 70 pigeons, which led to passenger pigeons becoming a plentiful food source. In 1897, less than 100 years after the first giant flock was seen, hunting had to be prohibited because population sizes had decreased dramatically. However, there were still several tens of thousands of passenger pigeons left. By 1900, wild passenger pigeons were extinct. In 1914, the last captive passenger pigeons became extinct, just about 100 years after these giant flocks were first observed. How could it happen that a bird which had been very abundant, became extinct? Since these giant flocks were gone, the passenger pigeons were unable to reproduce, neither in the wild nor in captivity. It was assumed that the animals needed a high population density to reproduce sufficiently.

Aren't there strong parallels to the European hamster? It was also originally unspectacular, just a normal animal in the fields. But all of the sudden hamsters became a pest in many areas. The pest situation ended in the mid/end of the $20^{\text {th }}$ century. And just a few decades later the populations are at the brink of extinction in many Western European countries and have been included on many red lists of Eastern European countries. Is it possible that a pest is a harbinger of extinction? Understanding pests might thus also help in understanding extinction.

\section{DISEASES}

That diseases increase mortality seems trivial, but in view of our limited knowledge of diseases in the European hamster and in view of the increased human mobility which might spread diseases which originally were restricted to certain regions, it should be addressed here. The following endoparasites have been found in the European hamster: Catenoltaenia pusilla, Rodentolepsis straminea, Aprostatandrya macrocephala, Taenia tenuicollis, Heligmosomoides travasossi, tapeworm cysticercus, and the larvae of nematodes (GotTSCHALK 1998). Many animals carried up to three endoparasite species. In the investigated areas, about $1 / 4$ of the animals were infected. Males were particularly affected; between $40 \%$ and $55 \%$ were endoparasite-ridden, up to $40 \%$ strongly, which should lower fitness considerably. Many further parasites and pathogens affecting the European hamster are known (NECHAY et al. 1977), but we still don't know to what extent these diseases influence population size.

As with many rodents, European hamsters are susceptible to cancer (ERNST et al. 1989). Whether their susceptibility has increased in recent years is not clear. One of the most frequent cancers are thymomas (Ghadially and Illman 
1965, Brandes et al. 2004). At first they seem to be induced by a virus, but in spite of an intense search, viruses could not be detected in animals which suffered from thymomas (BRANDes et al. 2004).

A disease which is not yet properly diagnosed in the European hamster is characterized by swollen feet. They were observed in captive animals (Fig. 3) and similarly in the wild (I. Petrova, pers. comm.). The feet must be extremely painful, since affected animals are barely able to walk and avoid strain on the feet (own observations). They are thus easy prey. The swollen feet resemble symptoms of a disease described in voles as brucellosis. It is caused by a bacterium of the genus Brucella (ZHELUDKov and TsIRELSON 2010) which recently developed a new species. One of them is Brucella microtis (DE BAGÜČs et al. 2010) which affects voles and persists in the soil (DE BAGÜČs et al. 2010, Al Dahouk et al. 2012). This also makes it dangerous for other, especially burrow dwelling, species. To the author's knowledge European hamsters are not yet tested for brucellosis.

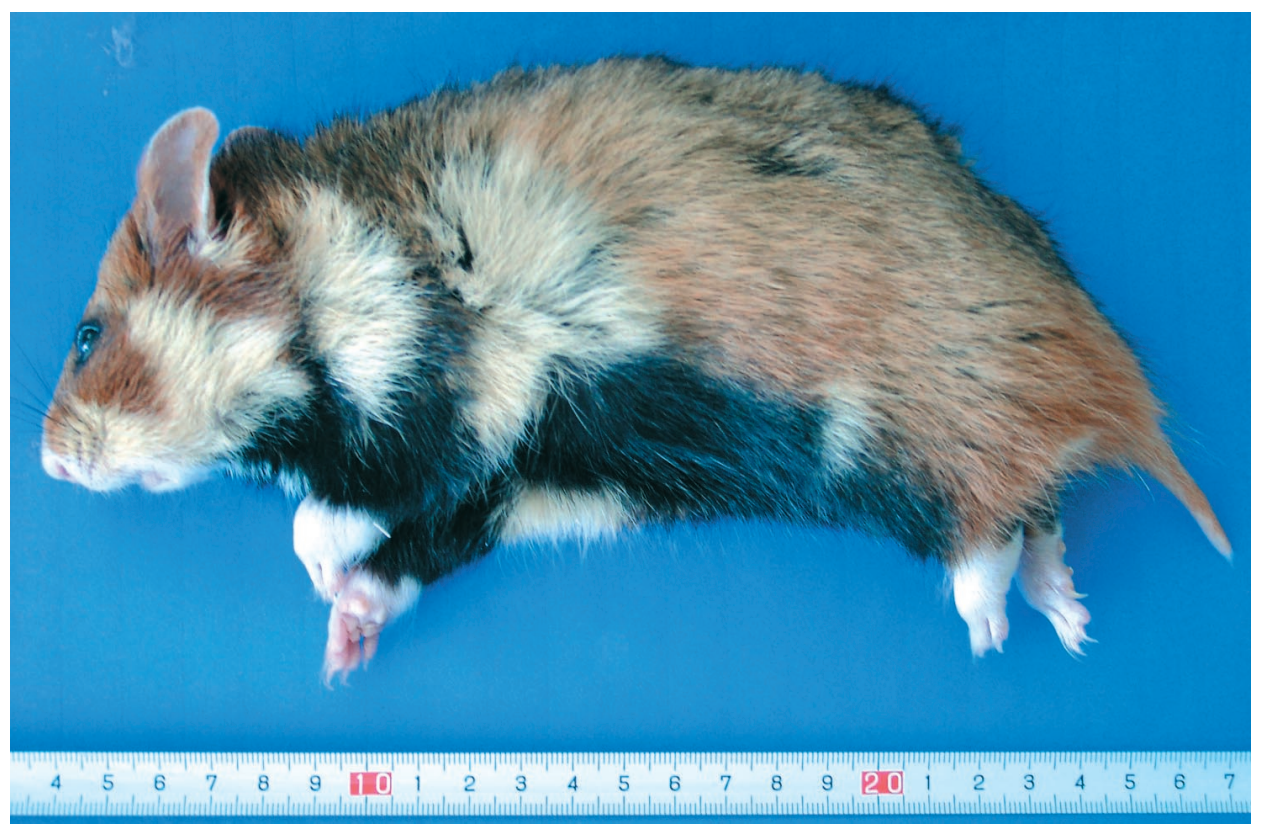

Fig. 3: A not yet diagnosed disease characterized by swollen feet in a female European hamster. The swollen feet are rather immobile and painful when strained

Another worrying disease is tularaemia which is caused by Francisella tularensis to which European hamster are very susceptible (GyuRANECZ et al. 2010). To make things worse, European hamsters are unable to produce antibodies against it and won't survive an infection (Gyuranecz et al. 2010). The lack 
of antibodies makes it difficult to detect its occurrence in the field and consequently animals might die from it without it being recognized. Research on diseases in European hamsters is urgently needed.

\section{WHY IS THE REPRODUCTIVE RATE INSUFFICIENT?}

Similar to passenger pigeons, the European hamster doesn't reproduce in sufficient numbers (LEIRS 2002). In the case of the passenger pigeons, it was assumed that a certain population density was necessary to stimulate reproduction. This might well account for European hamsters. In old reviews, when population densities were still high, 2-3 litters were given for normal years and 4 or even 5 litters per female for favourable years (NeCHAY et al. 1977, GRULich 1986). In the past two decades the latter has not been described, but 2-3 litters were still considered normal in the early 21 st century (LEIRS 2002). Now, 1-2 litters per year per female (pers. comm. with participants of the 19th meeting of the International Hamster Workgroup in Herkenrode) are normal. Only rarely a female raises 3 litters in a year.

Interestingly, the timing of reproduction seems to have changed. While in old literature, in reviews and in laboratory studies, it was found that the reproductive phase, i.e. when males and females have fully developed gonads lasts 4.5 months from early/mid April to mid August (Vohralík 1974, Krsmanovic et al. 1984, Nechay 2000, Monecke and Wollnik 2005) or even up to 6-7 months (March to September (Grulich 1986). A more recent study in Saxony Anhalt showed that this duration was not matched for seven consecutive years (KAYSER and Stubbe 2002, Weinhold and Kayser 2006). While the end of the reproductive phase approximated the normal end in some years, the beginning was always largely delayed, in the worst year by 2.5 months. The remaining duration of the reproductive phase was too short to raise more than two litters, often having only one litter.

Why is this so? One possible hypothesis might be climate change. This seems a paradox since climate change usually advances seasonal timing (VISSER et al. 2010). In European hamsters, the end of hibernation is triggered by a socalled circannual clock (MONECKE et al. in press), an endogenous timing mechanism which tells the hamster in its hibernacula when winter is over and hibernation has to be stopped to become reproductive in time. In the hibernacula, the hamsters have information neither on time nor on season, since it is completely dark inside and temperature stays rather constant. They experience neither increasing day length nor increasing spring temperatures but instead they rely on this circannual clock to end hibernation in time. However, it seems that the circannual clock of European hamsters is delayed in recent years and in many regions. The yearly resetting of this circannual clock occurs under natural conditions in mid July (SABOuREAu et al. 1999; MoneCKe et al. 2009), when the animals remark the decrease in photoperiod after the summer solstice. As a consequence, gonadal regression is initiated (visible four weeks later) (MONECKE et al. 2006) and the preparations for winter are started. To be able to detect the 
shortening of day length so soon after the summer solstice, when photoperiod decreases by only ca. one minute per day, a special, very precise activity pattern is necessary (Monecke and Wollnik 2005, Monecke et al. 2006; Monecke et al. in press). This activity pattern is only expressed between mid-May and mid-July when the European hamsters are sensitive to changes in photoperiod (Saboureau et al. 1999, Monecke and Wollnik 2005, Monecke et al. 2006, Monecke et al. 2009). It has been shown that an early perception of the shortening of photoperiod leads to a delay in the consecutive reproductive phase (Monecke et al. 2009). A disturbance of the activity pattern might lead to a disturbed perception of this important environmental signal. Such a disturbance might be harvest. Nowadays harvest has advanced in many Western European countries from mid July to as early as mid June which coincides with the hamsters' phase of extreme sensitivity. An anecdotal report showed that after harvest, their activity pattern changed to complete nocturnal activity, atypical for the season (WENDT 1989). Thus, as a burrow dwelling animal, the hamsters are spending the day in the darkness of their burrows and venturing out only at night when it is dark, too. As a consequence the hamsters would experience constant darkness after harvest which might be interpreted by the animal as extremely short days, resulting in the circannual clock being incorrectly reset.

Also, light pollution might impair the perception of the shortening of photoperiod after the summer solstice and thus the timing of the next onset of the reproductive phase. European hamsters are synanthropic and thus settle close to highly light polluted human settlements.

Another potential explanation can be developed from our knowledge on the circadian clock, i.e. the endogenous rhythm which drives the sleep-wake cycle. This clock including its anatomical and molecular basis is well described (Dunlap et al. 2003). We know much less about the circannual clock, but whatever is discovered is analogous to what we know from the circadian clock. The human circadian clock shows an inter-individual variability in the circadian timing (Roenneberg et al. 2003, Roenneberg et al. 2007). The plot of mid-sleep times of humans shows a Gaussian distribution ranging from early chronotypes which go to bed early and which get up early and late chronotypes which do both late. An early chronotype has problems to stay awake at social events in the evening, the late chronotype has problems to be at high performance in the morning when work starts. Such chronotypes in humans are at least partly based on genetics (Roenneberg et al. 2003) thus they are heritable.

Little is known about inter-individual variability in seasonal timing. In European hamsters two works suggest that, indeed there is a bit variability in the timing of the reproductive phase (Franceschini-Zink and Millesi 2008b, MoneCKe et al. 2011). This may be due to a variety of reasons, among them age and body conditions of the females, but let's assume that there is also a heritable component in the seasonal chronotype. If this is the case, there has been a selection pressure against animals which terminate hibernation and start reproduction early in the year for the past three centuries. European hamsters where hunted for two reasons. The first was for pest control whenever it was necessary. 
The second, however, was for fur-trapping which occurred in the early spring, when the fur quality is optimal (Sulzer 1774). Thus, each year the animals which emerged earliest from hibernation were trapped. Those early emerging animals would most likely have reproduced earlier than late emerging ones.

The constant hunting of early emerging animals might have led to a loss of an early seasonal chronotype, which would have dramatic effects on the population. It has been shown that females which start the reproductive phase early raise more offspring then females which start later, though both spend a similar time-span for reproduction (Franceschini-Zink and Millesi 2008b). Moreover, according to what we know on ontogeny, the first litter of early reproducing females has a high chance to reach puberty and become reproductive in the year of birth (Nechay 2000, Kirn 2004, Franceschini-ZinK and Millesi $2008 \mathrm{~b}$, Monecke et al. own data) which would boost the reproductive output of a population. The early born pups are thus of highest importance for the survival of a population (Ulbrich and KAYSER 2004), but in recent years such early litters and young reproducing animals are barely observed. It is possible that this is a sustained effect of fur trapping in the past.

Presently, we have a selection pressure against late reproducing animals. In many regions the use of new crop varieties and/or climate change allows farmers to harvest earlier. In recent years, crop harvest often occurs as early as June in Western Europe. All offspring which are born later most likely have problems to build up a sufficient food stock for winter. Thus, after the possible loss of early breeding animals there might be now a strong shortening of the duration of the phase in which offspring can be raised successfully. In total this is a very dramatic threat for the hamsters.

\section{HOW CAN WE IMPROVE THE SITUATION?}

This review listed many potential reasons for regional or global declines of European hamsters which have no direct connection to modern agriculture. It makes clear that the reasons for decline are very complex and that we are still far from understanding. Research on agricultural history, soil quality, ecology, physiology, reproduction and diseases should have highest priority.

Until new solutions are found, two emergency measures might be helpful in breeding centres.

Conserve the early breeding phenotype.

For efficiency reasons, breeding often starts only when it is likely that all animals are reproductive, i.e. including animals of the late phenotype. However, the fecundity of females is not constant over the reproductive period (MONECKE et al. 2011) and early animals might have passed their maximum fecundity when breeding finally starts in the centres. Their reproductive success might be reduced compared to late females for which the breeding schedule is matched better. Choosing breeding dates thus causes unintentional selection against 
early breeding animals. Instead, monitoring body weight and reproductive state of females regularly from mid March on would allow starting breeding on an individual basis ca. 2-3 weeks after the vagina is open. By doing so, the interindividual variety in timing of reproduction can be maintained.

\section{Increase the genetic diversity.}

Due to the complexity of the present and past situation, we do not know yet the reason(s) for the decline of European hamsters. However, it is clear that European hamsters are currently not well adapted to their environment. In evolution, the adaptation to a given environment is achieved by mutations or the selection for the best suitable allele. However, due to the decline of population, their genetic variability is quite low and, as a consequence, most likely inflexible. How can we increase it? We can learn from a study in humans, in which the number of de novo mutations in children was monitored with respect to their parents' age at conception of the child (Kong et al. 2012). Seventy eight parentchild trios were studied. While in the child the number of de novo mutations on the maternal chromosome was very low (mean 14.2) and basically unchanged with age of the mother, de novo mutations on the paternal chromosome were much higher, about 40, when the father was 16 years old and increased steadily with age of the father to about 100 at an age of 46 years. The difference in the mutation rate on maternal and paternal chromosomes is explained by the fact that all of the 23 chromosome replications preceding the production of a mature ovum in human females are completed before birth (CROW 2000). In contrast, spermatogenesis occurs throughout the reproductive life of the males so that the number of chromosome replications increases with age. The sperm of a 20 year old man has undergone 7 times more chromosome replications than an ovum, and the sperm of a 40 years old man 25 times more (CROW 2000).

We could take advantage of this and increase the genetic variability in breeding programmes for reintroduction by using "old" European hamster males for breeding. It should be pointed out that with "old" not over-aged males are meant. In the lab, breeding of three years old males (after their third hibernation) was not successful (MonecKe et al. 2011). However, two years old males (after their second hibernation), which due to their body size would have highest chances to mate under natural conditions, could well serve this purpose in the colonies. Their offspring should carry more mutations. By that, the genetic variability and the adaptive flexibility, at least of the reintroduced hamster population might increase. Incorporating the two years old males in the breeding program overcomes another problem of European hamsters: even though old literature states that European hamsters have a life expectancy of more than 34 years (REZnik et al. 1976, ERnst et al. 1989, NeChay 2000), today in the wild only very few males exceed the yearling stage (KAyser and STubbe 2002, Franceschini-Zink and Millesi 2008a). Thus, there are no old males left which could reproduce. Consequently, there is only little chance that the genetic variability increases quickly. Furthermore, in captivity, most animals die from 
cancer (ERnSt et al. 1989; BRANDEs et al. 2004), which in males develops in most cases in the autumn or spring after their first breeding period (own unpublished observations). If they survive this "breakpoint" in life, they can become several years old (own unpublished observations). If there is a heritable component in the predisposition for cancer, these "survivors" do not have it. In contrast, when using only yearlings for breeding, cancer might be unintentionally spread in the offspring since it develops in the parental generation only after the breeding season.

\section{CONCLUSION}

This article has demonstrated a small part of the complexity of possible reasons which might be causing the dramatic global decline of the European hamster. We are still far from understanding what is going on. Some emergency measures such as breeding and reintroduction increase the time span we have to find the cause(s) before their extinction. We are on a good path but we need to go the next step now and analyse the situation in detail. We need to understand the past and present threats which are causing a decline in hamster populations, either by increasing mortality or reducing reproduction. In addition, we will have to anticipate possible future threats as for example climate change to avoid worsening of the situation.

\section{Acknowledgements}

This work was supported by the German Wildlife Foundation.

\section{CZY ROZPATRZELIŚMY WSZYSTKO? ALTERNATYWNE PRZYCZYNY WYGINIĘCIA CHOMIKA.}

W 2002 roku LEIRs (2002), biolog zajmujący się biologią szkodników, obliczył szanse przetrwania chomika europejskiego (Cricetus cricetus) wykorzystując dane dostarczone przez uczestników spotkania The International Hamster Workgroup odbywającego się w Tongren. Jego model oparty był głównie na danych demograficznych dotyczących rozrodczości i przewidział, że chomik europejski wyginie w zachodniej Europie w przeciągu następnych 50 lat. Od tamtego czasu średnia wielkość miotów wyprowadzonych przez samicę w ciągu roku zmalała z 2-3 do 1-2 młodych. Dlatego też należy się obawiać, że pozostały czas to jedynie połowa czasu przewidzianego modelem i wyginięcie może nastąpić około roku 2030. Jednakże, od 2002 roku środki ochrony chomika zostały zdecydowanie ulepszone, wśród nich należy wymienić dwa kamienie milowe: (1) jesteśmy w stanie wyhodować w niewoli wystarczającą liczbę chomików oraz (2) większość wypuszczonych na wolność osobników przeżywa do okresu rozrodczego. W świetle tych faktów możemy obecnie stwierdzić, iż dopóki takie programy rozrodu i wypuszczania na wolność chomika będą trwały, dopóty chomik europejski nie wyginie. Jednakże, nie osiągnęliśmy jeszcze takiego stanu, w którym możemy z przekonaniem powiedzieć, że chomiki przetrwają bez pomocy człowieka, czyli w momencie zaprzestania reintrodukcji. Praca nad osiągnięciem tego 
stanu to zadanie następnych lat. Ten artykuł przeglądowy może być zaczątkiem tej pracy. Analizuje on, oprócz aspektów współczesnego rolnictwa, czynniki, które potencjalnie mogą niekorzystnie wpływać na przetrwanie chomika i tym samym poszukuje parametrów, które do tej pory nie były brane pod uwagę w programach ochrony tego gatunku. Rozważaniom poddane są dane historyczne, a także obserwacje i badania nad innymi gatunkami.

Ponadto, przedstawione są nowe informacje dotyczące podziemnego życia chomika europejskiego w zewnętrznych terrariach, które wskazują glebę jako możliwy element siedliskowy wymagający większej uwagi w planowaniu działań ochronnych. Jest to jednak przypuszczenie, który musi być potwierdzone badaniami. Intencją tego artykułu jest rozpoczęcie żywej dyskusji właśnie na temat takich potencjalnych, alternatywnych przyczyn spadku liczebności chomika europejskiego. Czy któraś z nich jest warta zbadania? Czy może coś przeoczyliśmy? Zostało już niewiele czasu.

\section{REFERENCES}

Al Dahouk S., Hofer E., Tomaso H., Vergnaud G., Le Flčche P., Cloeckaert A., Koylass M.S., Whatmore A.M., Nöckler K. and Scholz H.C. 2012: Intraspecies biodiversity of the genetically homologous species Brucella microti. Applied and Environmental Microbiology 78: 1534-1543.

Allert J. and Löw S. 2011: Rotmilan (Milvus milvus) als Prädator vom Feldhamster (Cricetus cricetus) im Landkreis Gotha (Thüringen, Deutschland) [Red kite (Milvus milvus) as predator of the Common hamster (Cricetus cricetus) in the administrative district Gotha (Thuringia, Germany). Säugetierkd Inf 8: 149-153.

Bihari Z. 2003: Regression in distribution of Hamster (Cricetus cricetus) in Hungary during the past fifty years. 11th meeting of the international hamster workgroup G Nechay, ed., Budapest, Hungary: 27-30.

Brandes K., Fend F., Monecke S., Teifke J.P., Breuer W. and Hermanns W. 2004: Comparative morphologic and immunohistochemical investigation of spontaneously occurring thymomas in a colony of European hamsters. Vet. Pathol. 41: $346-352$.

Coburn D.K. and Geiser F. 1996: Daily torpor and energy savings in a subtropical blossom-bat, Syconycteris australis (Megachiroptera). Adaptions to the cold - 10th international symposium on hibernation F Geiser, A.J. Hulbert and S.C. Nicol, eds, Cradle Mountains, Tas.: 39-45.

Crow J.F. 2000: The origins, patterns and implications of human spontaneous mutation. Nature Reviews Genetics 1: 40-47.

de Bagüčs M.P., Ouahrani-Bettache S., Quintana J.F., Mitjana O., Hanna N., Bessoles S., Sanchez F., Scholz H.C., Lafont V., Köhler S. and Occhialini A. 2010: The new species Brucella microti replicates in macrophages and causes death in murine models of infection. The Journal of infectious diseases 202: 3-10.

Dunlap J.C., Loros J.L. and DeCoursey P.J. 2003: Chronobiology: Biological Timekeeping, Sinauer Associates.

Eisentraut M. 1928: Über die Baue und den Winterschlaf des Hamsters (Cricetus cricetus L.) [About the burrows and the hibernation in the hamster (Cricetus cricetus L.)]. Z Säugetierkd 3: 172-208.

Ernst H., Kunstyr I., Rittinghausen S. and Mohr U. 1989: Spontaneous tumours of the European hamster (Cricetus cricetus L.). Z. Versuchstierkd 32: 87-96. 
Feoktistova N.Yu., Surov A.V., Nikolay N. Tovpinetz N.N., Kropotkina M.V., Bogomolov P., Siutz C., Haberl W., Hoffmann I.E. 2013: The Common hamster as a synurbist: a history of settlement in European cities. Zoologica Poloniae, 58(3-4): 113-126.

Franceschini-Zink C. and Millesi E. 2008a: Population development and life expectancy in Common hamsters. 13th meeting of the International Hamster Workgroup (2005) - The Common hamster (Cricetus cricetus): Perspectives on an endangered species E. Millesi, H. Winkler and R. Hengsberger, eds, Illmitz/Vienna (Austria): 45-59.

Franceschini-Zink C. and Millesi E. 2008b: Reproductive performance in female Common hamsters. Zoology (Jena) 111: 76-83.

Frenz L. 2012: Lonesome George oder das Verschwinden der Arten [Lonesome George or the disappearance of species], Rowohlt, Berlin.

Ghadially F.N. and Illman O. 1965: Naturally occurring thymomas in the European hamster. J. Pathol. Bacteriol 90: 465-469.

Gottschalk C. 1998: Endoparasiten des Feldhamsters (Cricetus cricetus L.) in SachsenAnhalt. [Endoparasites of the European hamster (Cricetus cricetus L.) in Saxony-Anhalt]. In Ökologie und Schutz des Feldhamsters [Ecology and protection of the European hamster], M Stubbe and A Stubbe, eds, pp 327-332, Martin-Luther-Universität Halle-Wittenberg, Halle/Saale.

Grulich I. 1981: Die Baue des Hamsters (Cricetus cricetus, Rodentia, Mammalia) [Burrows of Cricetus cricetus (Rodentia, Mammalia)]. Folia Zool. 30: 99-116.

Grulich I. 1986: The reproduction of Cricetus cricetus (Rodentia) in Czechoslovakia. Acta Sc. Nat. Brno 20: 1-56.

Gyuranecz M., Denes B., Dan A., Rigo K., Foldvari G., Szeredi L., Fodor L., Alexandra S., Janosi K., Erdelyi K., Krisztalovics K. and Makrai L. 2010: Susceptibility of the Common hamster (Cricetus cricetus) to Francisella tularensis and its effect on the epizootiology of tularemia in an area where both are endemic. J. Wildl. Dis. 46: 1316-1320.

Horal D. 2011: Eastern Imperial Eagle (Aquila heliaca) in the Czech Republic. Acta Zoologica Bulgarica 63: 55-59.

Kayser A. and Stubbe M. 2002: Untersuchungen zum Einfluss unterschiedlicher Bewirtschaftung auf den Feldhamster Cricetus cricetus (L.) einer Leit- und Charakterart der Magdeburger Börde. [Investigations on the impact of different field-management on the European hamster Cricetus cricetus (L.) a characteristic species of the Magdeburger Börde]. Ministerium für Raumordnung, Landwirtschaft und Umwelt, Halle.

KIRN N. 2004: Ontogenese des Europäischen Feldhamsters (Cricetus cricetus) unter dem Einfluß verschiedener prä- und postnataler Photoperioden [Ontogeny in the European hamster (Cricetus cricetus) in different pre- and postnatal photoperiods]. Inaugural dissertation. Institut of Zoology, pp 123, University of veterinary medicine Hannover.

Kong A., Frigge M.L., Masson G., Besenbacher S., Sulem P., Magnusson G., Gudjonsson S.A., Sigurdsson A., Jonasdottir A., Jonasdottir A., Wong W.S.W., Sigurdsson G., Walters G.B., Steinberg S., Helgason H., Thorleifsson G., Gudbjartsson D.F., Helgason A., Magnusson O.T., Thorsteinsdottir U. and Stefansson K. 2012: Rate of de novo mutations and the importance of father's age to disease risk. Nature 488: 471-475. 
Kramer F. 1956: Über die Winterbaue des Hamsters (Cricetus cricetus L.) auf zwei getrennten Luzerneschlägen [About the winter burrows of the hamster (Cricetus cricetus L.) on two separate lucerne fields]. Wissenschaftliche Zeitschrift der Martin-Luther-Universität Halle-Wittenberg, Mathematisch-Naturwissenschaftliche Reihe 5: 673-682.

Krsmanovic L., Mikes M., Habijan V. and Mikes B. 1984: Reproductive activity of Cricetus cricetus L. in Vojvodina-Yugoslavia. Acta Zool. Fennica 171: 173-174.

LEIRS H. 2002: Conservation advices based on rodent pest biology: the case of the hamster. 10th Meeting of the International Hamsterworkgroup S. Mercelis, A. Kayser and G. Verbeylen, eds, Tongeren: 82-84.

Malan A. 2011: Mammalian hibernation, as illustrated by studies performed in Strasbourg and especially on the European hamster. 18th meeting of the International Hamster Workgroup (2011) - From fundamental research to population management: Refining conservation strategies for the European hamster [Cricetus cricetus L] S. Monecke and P. Pévet, eds, Strasbourg (France): 12-14.

Monecke S., Bonn D., Reibel-Foisset S. and Pévet P. 2011: Breeding success in aged female Common hamsters (Cricetus cricetus). Säugetierkd. Inf. 8: 121-129.

Monecke S., Malan A. and Wollnik F. 2006: Asymmetric control of short day response in European hamsters. J. Biol. Rhythms 21: 290-300.

Monecke S., Saboureau M., Malan A., Bonn D., Masson-Pévet M. and Pévet P. 2009: Circannual phase response curves to short and long photoperiod in the European hamster. J. Biol. Rhythms. 24: 413-426.

Monecke S. and Wollnik F. 2005: Seasonal variations in circadian rhythms coincide with a phase of sensitivity to short photoperiods in the European hamster. J. Comp. Physiol. [B] 175: 167-183.

Monecke S., Wollnik F. and Pévet P. in press: The circannual clock in the European hamster - how is it synchronized by photoperiodic changes? In Annual, lunar and tidal clocks - patterns and mechanisms of nature's enigmatic rhythms, H Numata and B Helm, eds, Springer Japan.

Nechay G. 2000: Status of hamsters Cricetus cricetus, Cricetus migratorius, Mesocricetus Newtoni and other hamster species in Europe, Council of Europe, Strasbourg Cedex.

Nechay G., Hamar M. and Grulich L. 1977: The Common Hamster (Cricetus cricetus [L.]); a Review. EPPO Bulletin 7: 255-276.

Neumann K., Kayser A., Mundt G., Gattermann R., Michaux J.R., Maak S. and JANSMAN H.A.H 2005: Genetic spatial structure of European common hamsters (Cricetus cricetus) - A result of repeated range expansion and demographic bottlenecks. Molecular Ecology 14: 1473-1483.

Reznik G., Reznik-Schüller H. and Mohr U. 1976: Clinical Anatomy of the European hamster Cricetus cricetus, L., U.S. Department of health, education and welfare, public health service, National Institut of Health.

Roenneberg T., Kuehnle T., Juda M., Kantermann T., Allebrandt K., Gordijn M. and Merrow M. 2007: Epidemiology of the human circadian clock. Sleep Medicine Reviews 11: 429-438.

Roenneberg T., Wirz-Justice A. and Merrow M. 2003: Life between clocks: Daily temporal patterns of human chronotypes. Journal of Biological Rhythms 18: $80-90$. 
Rusin M.Y., Banaszek A. and Mishta A.V. 2013: The common hamster (Cricetus cricetus) in Ukraine: evidence for population decline. Folia Zool. 62: 207-213.

Saboureau M., Masson-Pévet M., Cangullhem B. and Pévet P. 1999: Circannual reproductive rhythm in the European hamster (Cricetus cricetus): Demonstration of the existence of an annual phase of sensitivity to short photoperiod. J. Pineal. Res. 26: 9-16.

Sidorov G.V., Kassal B.Y., Goncharova A.V. and Vakhrushev K.V. 2011: Theriofauna of Omsk oblast: game species of rodents [in Russian], Nauka (Publishing house „Amphora”), Omsk.

Song X., Körtner G. and Geiser F. 1996: Interrelations between metabolic rate and body temperature during entry into daily torpor in Sminthopsis macroura. Adaptions to the cold - 10th international symposium on hibernation F. Geiser, A.J. Hulbert and S.C. Nicol, eds, Cradle Mountain, Tas.: 39-45.

Stubbe M. and Stubbe A. 1998: Der Feldhamster (Cricetus cricetus L.) als Beute von Mensch und Tier sowie seine Bedeutung für das Ökosystem [The European hamster (Cricetus cricetus L.) as prey of human and animal as well as it's importance for the ecosystem]. In Ökologie und Schutz des Feldhamsters [Ecology and protection of the European hamster], M. Stubbe and A. Stubbe, eds., pp 81-86, Martin-Luther-Universität Halle-Wittenberg, Halle/Saale.

Sulzer F.G. 1774: Versuch einer Naturgeschichte des Hamsters [Attempt of a natural history of the hamster], Verlag Naturkunde, Hannover, Berlin-Zehlendorf.

Tkadlec E., Heroldova M., Víš́ková V., Bednḱř M. and Zejda J. 2012: Distribution of the Common hamster in the CzechRepublic after 2000: retreating to optimum lowland habitats. Folia Zool. 61: 246-253.

Ulbrich K. and Kayser A. 2004: A risk analysis for the common hamster (Cricetus cricetus). Biological Conservation 117: 263-270.

Visser M.E., Caro S.P., Oers K.V., Schaper S.V. and Helm B. 2010: Phenology, seasonal timing and circannual rhythms: Towards a unified framework. Philosophical Transactions of the Royal Society B: Biological Sciences 365: 3113-3127.

Vohralík V. 1974: Biology of the reproduction of the Common hamster, Cricetus cricetus (L.). Vestnik Ceskoslovenské Spolecnosti Zoologicke 38: 228-240.

Weinhold U. and Kayser A. 2006: Der Feldhamster [The European hamster], Westarp Wissenschaften-Verlagsgesellschaft $\mathrm{mbH}$, Hohenwarsleben.

Wendt W. 1989: Zum Aktivitätsverhalten des Feldhamsters, Cricetus cricetus L., im Freigehege [About the activity bahaviour of European hamsters, Cricetus cricetus L., in outdoor enclosures. Säugetierkundliche Informationen 3: 3-12.

Wichmann G. 2011: The situation of the eastern Imperial Eagle aquila heliaca in Austria. Acta Zoologica Bulgarica 63: 37-40.

Zheludkov M.M. and Tsirelson L.E. 2010: Reservoirs of Brucella infection in nature. Biology Bulletin 37: 709-715.

Ziomek J. and Banaszek A. 2007: The Common hamster, Cricetus cricetus in Poland: Status and current range. Folia Zool. 56: 235-242. 